\title{
Hydrogen ion efflux differences in soybean roots associated with yields $\mathbf{s}^{1,2}$
}

\author{
Gumersindo Ramírez-Oliveras,', Charles A. Stutte' \\ and Essaú Orengo-Santiago
}

J. Agric. Univ. P.R. 81(3-4):159-180 (1997)

\begin{abstract}
Significant differences in hydrogen ion $(H \cdot)$ efflux from soybean roots among soybean cultivars were found ranging from 0.5 to $2.4 \mathrm{pH}$ units in 24 $h$. The hydrogen ion efflux was positively correlated with the cultivar's seed yield in three different soil series. On highly leached, low cation exchange capacity (CEC) Oxisol (less than $10 \mathrm{cmol} / \mathrm{kg}$ ), the cultivars with high $\mathrm{H}^{+}$efflux capacity yielded highest and accumulated the highest amount of nutrients at flowering. All macronutrients, except for $\mathrm{Ca}$ and $\mathrm{Mg}$, decreased at the beginning of the seed stage. Hydrogen ion efflux was positively correlated to leaf $\mathrm{K}$ and the $\mathrm{K} /(\mathrm{Ca}+\mathrm{Mg})$ ratio. The $\mathrm{K} /(\mathrm{Ca}+\mathrm{Mg})$ ratio was positively correlated to biomass and yields, thus suggesting nutrient accumulation up to seed production. Results from the medium CEC Ultisol (10 to $20 \mathrm{cmol} / \mathrm{kg}$ ) were similar to those from the low CEC soil. On the high CEC Vertisol (above $35 \mathrm{cmol} / \mathrm{kg}$ ), the cultivars with high $\mathrm{H}^{*}$ efflux depleted the rhizosphere soil zone for $\mathrm{K}$ faster than those with low $\mathrm{H}^{+}$efflux, giving positive correlations for seed and biomass yields but negative correlations with leaf $K$ and the $K J$ $(\mathrm{Ca}+\mathrm{Mg})$ ratio.
\end{abstract}

Key words: Hydrogen ion efflux, soybean, Glycine max

\section{RESUMEN}

El flujo de iones de hidrógeno por la raiz de soya y su relación con el rendimiento

Se evaluó el potencial para emanar iones de hidrógeno $\left(H^{*}\right)$ por la raiz de seis cultivares de habichuela soya, Glycine max (L.) Merr. Se establecieron experimentos en dos zonas geográficas con marcadas diferencias en suelo y clima. Se encontraron diferencias significativas en el flujo de $\mathrm{H}^{+}$por las raices entre las cultivares de habichuela soya que fluctuaron desde 0.5 hasta 2.4 unidades de $\mathrm{pH}$ en 24 horas. La correlación entre el flujo de $\mathrm{H}$. y el rendimiento fue positiva para los tres suelos seleccionados. El flujo de $\mathrm{H}^{\text {. }}$ se correlaciono positivamente con el contenido foliar de potasio y la proporción $\mathrm{K} /(\mathrm{Ca}+\mathrm{Mg})$. La correlación entre biomasa y rendimiento con la proporción de $\mathrm{K} /(\mathrm{Ca}+\mathrm{Mg})$ fue positiva, indicando una acumulación de nutrimentos hasta la produccion. Los resultados obtenidos en el suelo Ultisol, con capacidad de intercambio catiónico (CIC) mediana (10 a $20 \mathrm{cmol} / \mathrm{kg}$ )

'Manuscript submitted to Editorial Board 22 January 1992.

The senior author acknowledges the dedicated assistance of José A. Rodriguez and Juan Alejandro Pardo in conducting these experiments.

Research Agronomist (now retired), Agricultural Experiment Station, UPR.

'Late Distinguished Professor, University of Arkansas.

"Assistant Horticulturist, Department of Horticulture. 
fueron similares a los obtenidos en el suelo con una CIC baja. En un suelo Vertisol, con $\mathrm{ClC}$ alta (mayor de $35 \mathrm{cmol} / \mathrm{kg}$ ), las cultivares con alto flujo de $\mathrm{H}^{\prime}$ agotaron el potasio de la rizosfera del suelo más rápidamente que aquellos cultivares con flujo de $\mathrm{H}^{+}$bajo, presentando una correlación positiva para rendimiento de semilla y biomasa pero negativa para el contenido foliar de potasio y la proporción $\mathrm{K} /(\mathrm{Ca}+\mathrm{Mg})$.

\section{INTRODUCTION}

Soybean [Glycine $\max$ (L.) Merr.] can provide high quality protein and therefore offers great potential as a food resource for the tropics. This crop is also a mainstay in the preparation of concentrated feed for livestock. Current high yields of soybeans are largely a result of good varieties, weed control and large amounts of fertilizers. Varietal selecction for high yield is made without consideration of the plant's capacity or efficiency in extracting nutrients from the soil. As fossil energy becomes more expensive and the costs of commercial fertilizers escalate, it is increasingly important to identify cultivars best suited for exploiting native nutrient resources of the soils.

Varietal differences in nutrient absorption rates have been determined for some crops (Glass and Perley, 1980; Osterhaut, 1936; Patterson, 1978). Some cultivars can adapt more effectively to a particular soil series as a function of the plant's hydrogen ion $\left(\mathrm{H}^{+}\right)$efflux capacity. This characteristic can be used as a screening method for lines efficient in nutrient absorption (Glass et al., 1981). Soybean cultivars must be screened as classified for the $\mathrm{H}^{+}$efflux potential. This potential can be correlated in the field to yield data for specific soils. The soybean cultivars used for this purpose have been selected for temperate climate cropping and would indicate similarities or differences, when yields and $\mathrm{H}^{+}$efflux are compared at two geographical locations. Experimental evidence supports the view that cation absorption takes place by means of an exchange of the cation for a $\mathrm{H}^{+}$at the root surface (Lundegarth, 1942; Lüttge and Higenbothem, 1979; Marré et al., 1974). The $\mathrm{H}$ efflux measured during salt accumulation has been interpreted as an active metabolically controlled process operating against the electrochemical activityr gradient of $\mathrm{H}^{*}$ (Leggett and Gilbert, 1969; Pitman, 1970; Pitman et al., 1975). The ratio between $\mathrm{K}^{+}$uptake and $\mathrm{H}^{+}$efflux ranges from 0.5 to 2.0 (Haschke and Lüttge, 1973; Marré et al., 1974). Once the proton gradient across the membrane collapses, immediate inhibition of $\mathrm{K}^{*}$ uptake results (Jin, 1979). Hydrogen ion efflux and $\mathrm{K}^{+}$ influx have been strongly correlated in both low- and high-K roots, although the $\mathrm{K} \cdot \mathrm{H} \cdot \mathrm{exchange}$ ratios have been consistently greater than. 2:1 (Class and Siddiqi, 1982; Pitman, 1970). A supply of photosynthate 
is essential to maintain $\mathrm{H}^{+}$efflux and root transport activity (Cheeseman and Enkoji, 1984). Hydrogen ion effux for the entire root complex has been reported at $5.0 \mu \mathrm{M} \mathrm{H}$ - per gram fresh weight per hour (Römheld et al., 1984). Soybean plants have shown positive responses in both shoot dry weight production and total ion uptake under hydroponic culture (Leggett and Frere, 1971).

\section{MATERIALS AND METHODS}

Soybean cultivar screening to determine hydrogen ion efflux capability was conducted in a controlled environment growth chamber programmed for 13 -h days at $55 \%$ relative humidity, and 11 -h nights at, $70 \%$ relative humidity. Incandescent, fluorescent, and cool-white lamps provided a radiant flux density of $40 \mathrm{w} / \mathrm{m}^{2}$ whereas day and night temperatures were maintained at 28 and $20^{\circ} \mathrm{C}$, respectively. Seeds of fourteen soybean cultivars were germinated in moistened vermiculite, and at the VI (unifoliate) stage plants of similar appearance were transferred to a nitrate nitrogen hydroponic culture of mineral nutrient solution in 0.9-L glass containers (Ferr and Cariness, 1977; Stutte et al., 1979).

A completely randomized block design was used with four replications of each soybean cultivar. Containers were rotated in situ daily to eliminate micro-environmental differences within the chamber. The solution was brought to volume daily, and every third day it was replaced by fresh solution.

When the plants reached the V3 to V4 growth stage they were transferred to a solution of $0.5 \mathrm{mM} \mathrm{CaSO}_{4}$ plus $0.1 \mathrm{mM} \mathrm{K}_{2} \mathrm{SO}_{4}$ of $\mathrm{pH} 7$ and kept there for a $24-h$ period. At the end of this period, the plants were removed and the solution was brought back to volume. The $\mathrm{pH}$ of the solution was measured under continuous stirring with a Fisher Accumet Model 750 Selective Ion Analyzer ${ }^{6}$. The recorded value was subtracted from the previous $\mathrm{pH}(7.0)$ and the difference was taken as a measure of $\mathrm{H}^{+}$efflux from the roots in a 24 -h period. The plants were oven dried at $74^{\circ} \mathrm{C}$ for $72 \mathrm{~h}$ to determine dry weight.

From the 14 cultivars screened, six were selected to represent early, midseason, and late maturity groups as well as high, medium, and low $\mathrm{H}^{+}$efflux. These selections were Pioneer 5482, Davis, Forrest, Lee 74, Hood 75 and Terra Vig 708 (Table 1).

"Mention of a trade name does not constitute a warranty of equipment or materials by the Agricultural Experiment Station of the University of Puerto Rico, nor is this mention a statement of preference over other equipment or materials. 
TABI.E 1. - Characteristics of the soybean cultivars evaluated.

\begin{tabular}{llccc}
\hline Cultivar & Parentage description Maturity group Growth type & $\Delta p H^{\prime}$ \\
\hline Pioneer 5482 & U.S. cultivar & V & D & $2.41 \mathrm{a}^{2}$ \\
Davis & D $49-2573 \times$ N45-1497 & VI & D & $1.98 \mathrm{~b}$ \\
Forrest & Dyer $\times$ Bragg & V & D & $1.44 \mathrm{~d}$ \\
Lee 74 & Lee $68 \times$ R66-1517 & VI & D & $1.71 \mathrm{c}$ \\
Hood 75 & U.S. cultivar & VI & D & $0.80 \mathrm{e}$ \\
Terra Vig 708 & U.S. cultivar & VII & D & $0.70 \mathrm{e}$
\end{tabular}

'Means in a column followed by the same letter are not significantly different $(\mathrm{P}<$ $0.05)$.

$\triangle \triangle \mathrm{pH}$ is the depression from $\mathrm{pH} 7$.

\begin{abstract}
ARKANSAS STUDY
The purpose of the Arkansas study was to correlate the controlled environment screening for $\mathrm{H}^{+}$efflux capacity with plant yield under field conditions. Soils where the cultivar performance trials took place had cation exchange capacities varying between 10 and $30 \mathrm{meq} / 100 \mathrm{~g}$ soil (W. E. Sabbe, personal communication; Soil Survey Staff, 1988). Yield data for 1982 (Longer et al., 1984), 1983 (Longer et al., 1983), and 1984 (Longer and Moore, 1985) were used to make the necessary statistical analyses. The three soils were Sharkey clay (Vertic Haplaquepts); Loring silt loam (Typic Fragiudalfs); and Crowley silt loam (Typic Albaqualfs) (Soil Survey Staff, 1978).
\end{abstract}

\title{
PUERTO RICO STUDY
}

The experiments were established at three locations, Isabela, Corozal and Lajas Substations. The soil at Isabela, Coto clay, is classified as Tropeptic Haplorthox, clayey, kaolinitic, isohyperthermic (Bonnet-Benítez, 1983; Lugo-López et al., 1973; Lugo-López and Rivera, 1976). The soil at Corozal, Corozal clay, is classified as Aquic Tropudults (Bonnet-Benítez, 1983; Lugo-López, et al., 1973; Lugo-López and Rivera, 1976); at Lajas the soil Fraternidad clay is classified as Udic Chromusterts, very fine montmorillonitic, isohyperthermic (Bonnet-Benitez, 1983; Lugo-López, et al., 1973; Lugo-López and Rivera, 1976). At Isabela the mean annual rainfall is about $1,630 \mathrm{~mm}$ (Table 2 ). Solar radiation ranges from 300 langleys/day in December to 600 langleys/ day in July.

Six determinate soybean cultivars were evaluated (Table 1). The experimental area was 0.0549 ha arranged in a randomized complete block design with four replications per treatment. Each plot consisted 
TABLE 2,-Total rainfall $(\mathrm{mm})$ and mean temperatures $\left({ }^{\circ} \mathrm{C}\right)$ for the experiment siles.

\begin{tabular}{|c|c|c|c|c|c|c|c|c|c|}
\hline \multirow[b]{3}{*}{ Month } & \multicolumn{3}{|c|}{ Isabela } & \multicolumn{3}{|c|}{ Corozal } & \multicolumn{3}{|c|}{ Lajas } \\
\hline & \multirow[b]{2}{*}{ Rainfall } & \multicolumn{2}{|c|}{ Temp } & \multirow[b]{2}{*}{ Rainfall } & \multicolumn{2}{|c|}{ Temp } & \multirow[b]{2}{*}{ Rainfall } & \multicolumn{2}{|c|}{ Temp } \\
\hline & & $\mathrm{L}$ & $\mathrm{H}$ & & L & $\mathrm{H}$ & & L & $\mathrm{H}$ \\
\hline July & 75.17 & 20.5 & 30.6 & 75.17 & 21.0 & 30.4 & 180.59 & 20.6 & 32.6 \\
\hline August & 204.97 & 21.0 & 31.3 & 96.53 & 21.1 & 31.6 & 97.03 & 20.7 & 32.9 \\
\hline September & 266.95 & 20.6 & 31.0 & 289.55 & 20.7 & 30.8 & 174.73 & 20.8 & 31.7 \\
\hline October & 250.18 & 19.8 & 30.6 & 254.74 & 20.3 & 30.4 & 11.1 .76 & 20.0 & 31.2 \\
\hline
\end{tabular}

of six rows spaced $0.6 \mathrm{~m}$ apart and $4.5 \mathrm{~m}$ long. Seeds were innoculated with Rhizobium and planted $3 \mathrm{~cm}$ deep and $7.5 \mathrm{~cm}$ apart in the row, giving a plant population of approximately 215,000 plants per hectare. Two border rows were used for leaf sampling, and the inner four were harvested for yield and biomass determinations.

All experimental plots were hand-weeded, and weekly sprays of Diazinon (1.3 L/ha) or Malathion (9.5 L/ha) + Dithane (2.2 kg/ha) were administered to control insects and prevent fungal diseases. No fertilizer was used on any of the experiments. Sprinkler irrigation was used when necessary to supply at least $40 \mathrm{~mm}$ of water weekly, including rainfall. Soil core samples were taken from 0 - to 15 -cm depths for mineral analyses (Table 3). Foliar samples consisted of leaves from lower, middle and upper leaf positions collected during flowering (R1) and pod formation (R5) from the two border rows of the experimental plots

TABlE 3.-Soil analyses for Oxisol (Isabela), Ultisol (Corozal), and Vertisol (Lajas).'

\begin{tabular}{lccc}
\hline Item & Isabela & Corozal & Lajas \\
\hline $\mathrm{pH}$ & 5.37 & 4.72 & 6.25 \\
CEC meq/100g & 7.7 & 15.30 & 39.0 \\
Sand $(\%)$ & 33.83 & 19.0 & 24.85 \\
Clay $(\%)$ & 59.79 & 61.53 & 48.07 \\
Silt $(\%)$ & 6.39 & 19.47 & 27.08 \\
$\mathrm{~K}(\mu \mathrm{g} / g)$ & 35 & 305 & 225 \\
$\mathrm{Ca}(\mu \mathrm{g} / \mathrm{g})$ & 734 & 1,198 & 3,554 \\
$\mathrm{Mg}(\mu \mathrm{g} / \mathrm{g})$ & 121 & 146 & 1,897 \\
$\mathrm{Na}(\mu \mathrm{g} / \mathrm{g})$ & 16 & 26 & 66 \\
$\mathrm{Fe}(\mu \mathrm{g} / \mathrm{g})$ & 2 & 4 & 2 \\
$\mathrm{Mn}(\mu \mathrm{g} / \mathrm{g})$ & - & 6 & - \\
$\mathrm{Al}(\mu \mathrm{g} / \mathrm{g})$ & - & 4 & - \\
\hline
\end{tabular}

Exchangeable cations as extracted by neutral normal $\mathrm{NH}_{4} \mathrm{OAC}$. 
(Fehr and Caviness, 1977). The two border rows were sampled at the beginning, middle, and end for a total of six leaf samples per plot and 24 leaf samples for each cultivar evaluated.

The Isabela experiment was harvested 91 days after planting, when more than $90 \%$ of the plant canopy had shed its leaves (Caldwell, 1973; Norman, 1978) and the pods were completely yellow (TeKrony et al., 1981). Whole plants were harvested for total biomass and yield determinations. A harvest index (HI) was calculated by dividing seed yield by biomass yield and multiplying the result by 100 (Gardner et al., 1985). The ratio $\mathrm{K} /(\mathrm{Ca}+\mathrm{Mg}$ ) was determined at the flowering stage (R1) and the beginning seed (R5) productive stage (Fehr and Caviness, 1977; TeKrony et al., 1981).

The second experiment was conducted at the Corozal Substation, 1ocated in the humid interior uplands. Total rainfall at this site from planting to harvest was $789 \mathrm{~mm}$ (Table 2). The Corozal experiment was harvested at physiological maturity, 136 days after planting (TeKrony et al, 1981). The procedures and parameters for sampling collection, harvesting and analyses of data were the same as those of Isabela.

The third experiment was established at Lajas Substation. Table 2 gives total rainfall and mean temperatures. The same parameters and procedures used at Isabela and Corozal were repeated at Lajas.

Statistical differences were determined by analysis of variance. Controlled environmental tests were analyzed as completely randomized designs, and the field experiments as randomized block designs. Significant differences were reported at the 0.05 level of probability as determined by LSD tests and Duncan's multiple range tests (Little and Hills, 1978). Each point in the figures represents the mean value of twenty $\mathrm{pH}$ readings. Significant differences for correlations at $\mathrm{P}<0.05$ were those values of $r \geq 0.81$ (Little and Hills, 1978).

\section{RESULTS AND DISCUSSION}

Controlled Environment Study

The amount of $\mathrm{H}^{+}$effluxed by roots varied significantly among soybean cultivars (Table 1). Differences in $\mathrm{H}^{+}$secretion have also been reported for barley cultivars (Glass et al., 1981). Hydrogen ion efflux, expressed in $\mathrm{pH}$ units, represents the hydrogen on concentration changes from $\mathrm{pH} 7(0.1 \mu \mathrm{MH}+/ \mathrm{L})$.

Changes greater than $2.0 \mathrm{pH}$ units are considered indicative of high $\mathrm{H} \cdot$ effluxing root whereas fewer than 2.0 but more than $1.0 \mathrm{pH}$ unit are considered to be intermediate, and less than $1.0 \mathrm{pH}$ unit change reflects a low degree of $\mathrm{H}^{*}$ efftux. The commercial cultivars Pioneer 5482 and 
Davis proved to be high $\mathrm{H}^{+}$efflux cultivars, Forrest and Lee 74 were medium and Hood 75 and Terra Vig 708 were low (Table 1).

The cultivars Pioneer 5482, Davis, and Forrest (high and medium $\mathrm{H}^{*}$ efflux) exhibited high yields at the Arkansas Research and Extension Centers Keiser, Marianna, and Stuttgart during the 1982 crop variety testing season (Longer et al.,1983). There was a positive correlation $(\mathrm{r}=0.69)$ at Keiser between the $\mathrm{H}^{+}$efflux and yields (Figure 1A). Cultivars exhibiting the greatest $\mathrm{H}$ - efflux occupy the higher positions on the line and those with the low $\mathrm{H}^{+}$efflux (Hood 75) occupy the lower positions. Data for Marianna (Figure 1B) experienced a steeper slope than that of data for Keiser. The slope of this line indicates a marked soil potential to bring out an individually different yield response from each cultivar in accordance with its $\mathrm{H}^{+}$efflux output. Rates of nutrient uptake vary among plant species, and these variations in absorption from the soil solution could be positively correlated to the particular plant's capacity for $\mathrm{H}+$ efflux output at the root surface (Glass et al., 1981; Vose, 1963). The cultivars apparently were more efficient in nutrient uptake at Marianna than at Keiser during 1982, as indicated by a steeper slope and higher yields. At the Stuttgart location there was a sharp separation in yield between the low and the high efflux cultivars, but their positioning around the plotted slope line remained similar, with cultivars Pioneer 5482, Davis, and Forrest attaining the highest yields (Figure 1C).

In 1983, Pioneer 5482 ( $\mathrm{pH} 2.4$ ) produced the highest yield among the six cultivars (Figure 2A) (Longer et al., 1984); however, the correlation between yield and $\mathrm{pH}$ was negative $(r=-0.93)$. The other high $\mathrm{H}^{+}$efflux cultivars did not perform as expected. Nevertheless, the pattern held in Marianna (Figure 2B) and in Stuttgart (Figure 2C) for the same year. At Marianna the positive correlation still held $(r=0.79)$, and the cultivars arranged themselves on the sloping line according to the $\mathrm{H}^{+}$efflux rankings. Plants with high and medium $\mathrm{H}^{+}$efflux had higher yields (almost 20\% higher) than those with low $\mathrm{H}$ efflux (Figure 2B). Pioneer $5482(\mathrm{pH}=2.4)$ was the highest producer and Terra Vig $708(\mathrm{pH}=07)$, the lowest. The slope for data at Marianna in 1983 was the same as that of 1982, thus indicating again this particular soil's capacity to recharge itself of available cations. There was a higher correlation $(x=0.79)$ than for the previous year between $\mathrm{H}^{+}$efflux and yields (Figure $2 \mathrm{~B}$ ). Cultivars spread in a similar pattern around the slope line from lowest to highest as in the previous year. At Stuttgart the high and medium $\mathrm{pH}$ cultivars had a $6 \%$ higher yield than the low pH cultivars (Figure $2 \mathrm{C}$ ). In 1984, at Keiser, the highest yields were those of Pioneer 5482 and Davis (Figure 3A) (Longer and Moore, 1985). The plotted line slope was 

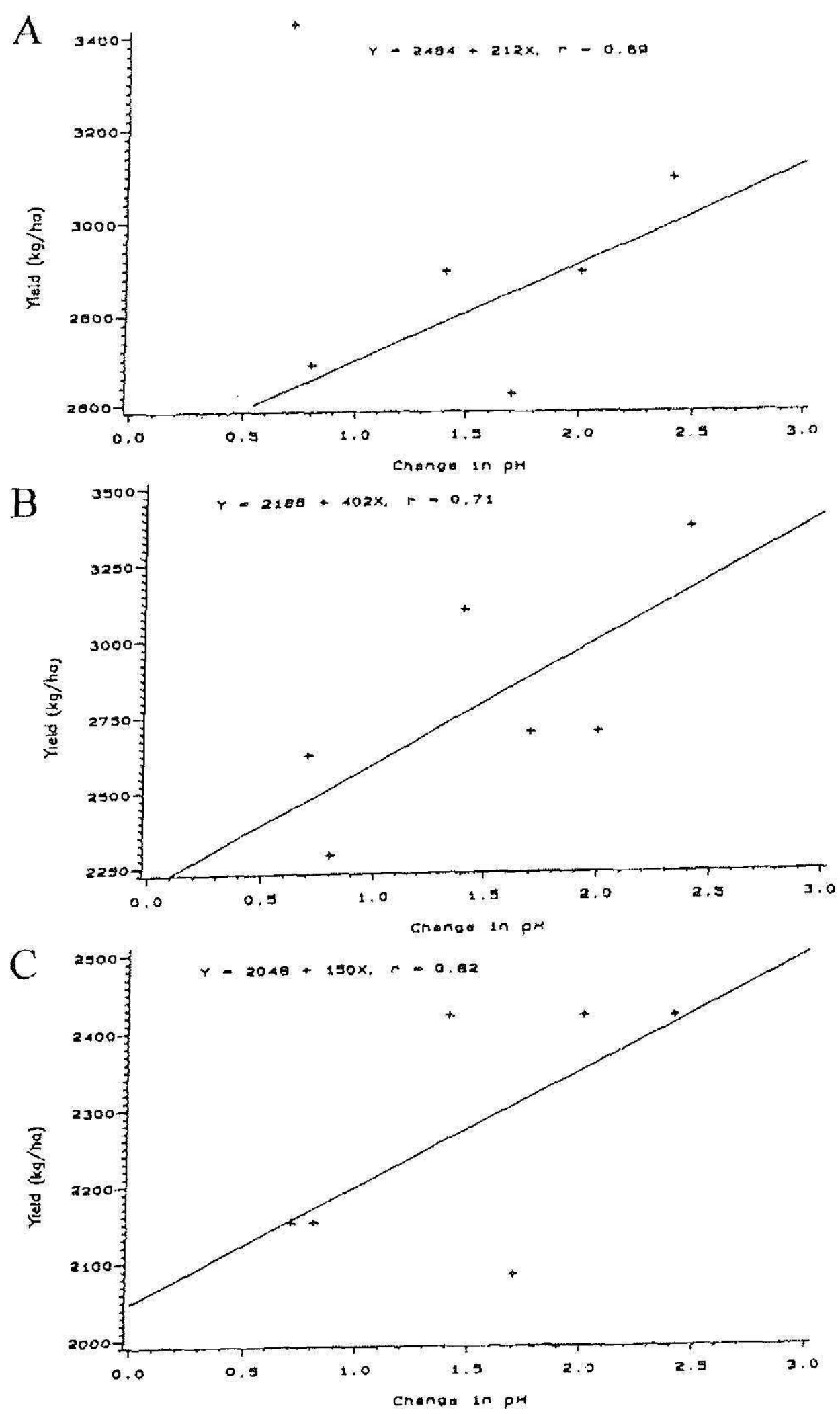

FIGURE 1. The association between change in pH and yields on (A) Sharkey clay (Keiser, 1982); (B) Loring sill loam (Marianna, 1982); and (C) Crowley silt loam (Stuttgart, 1982). 


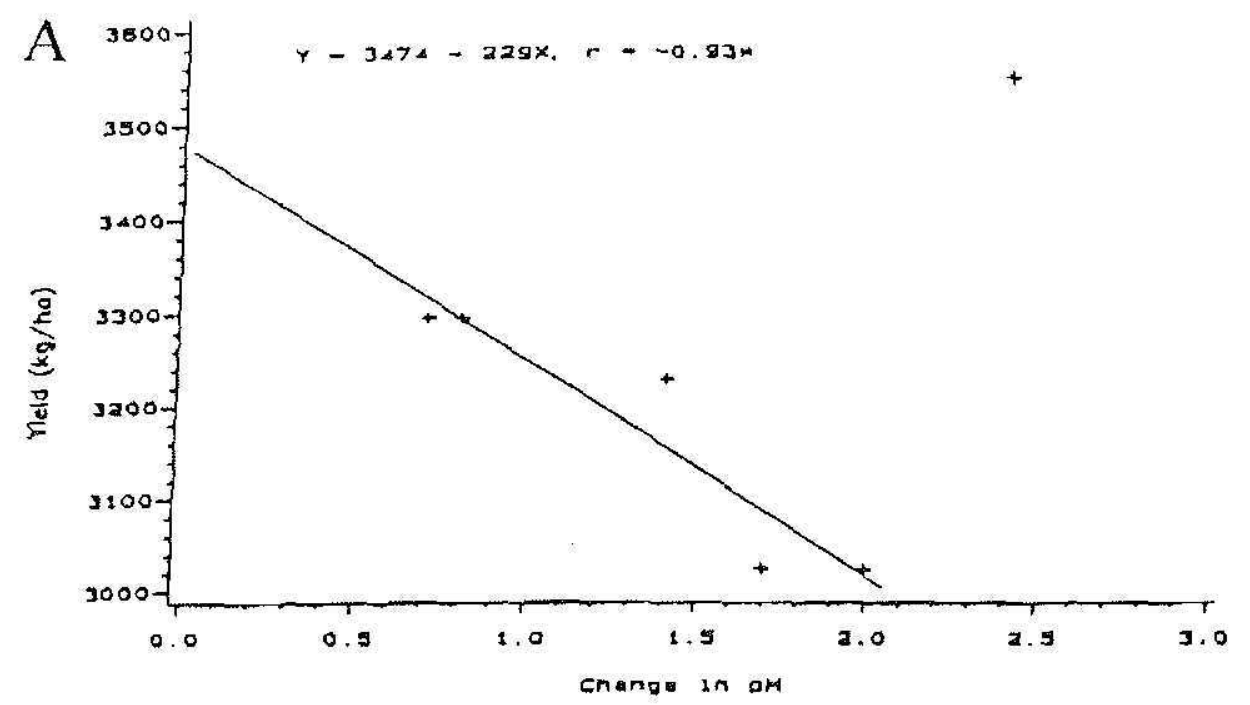

B
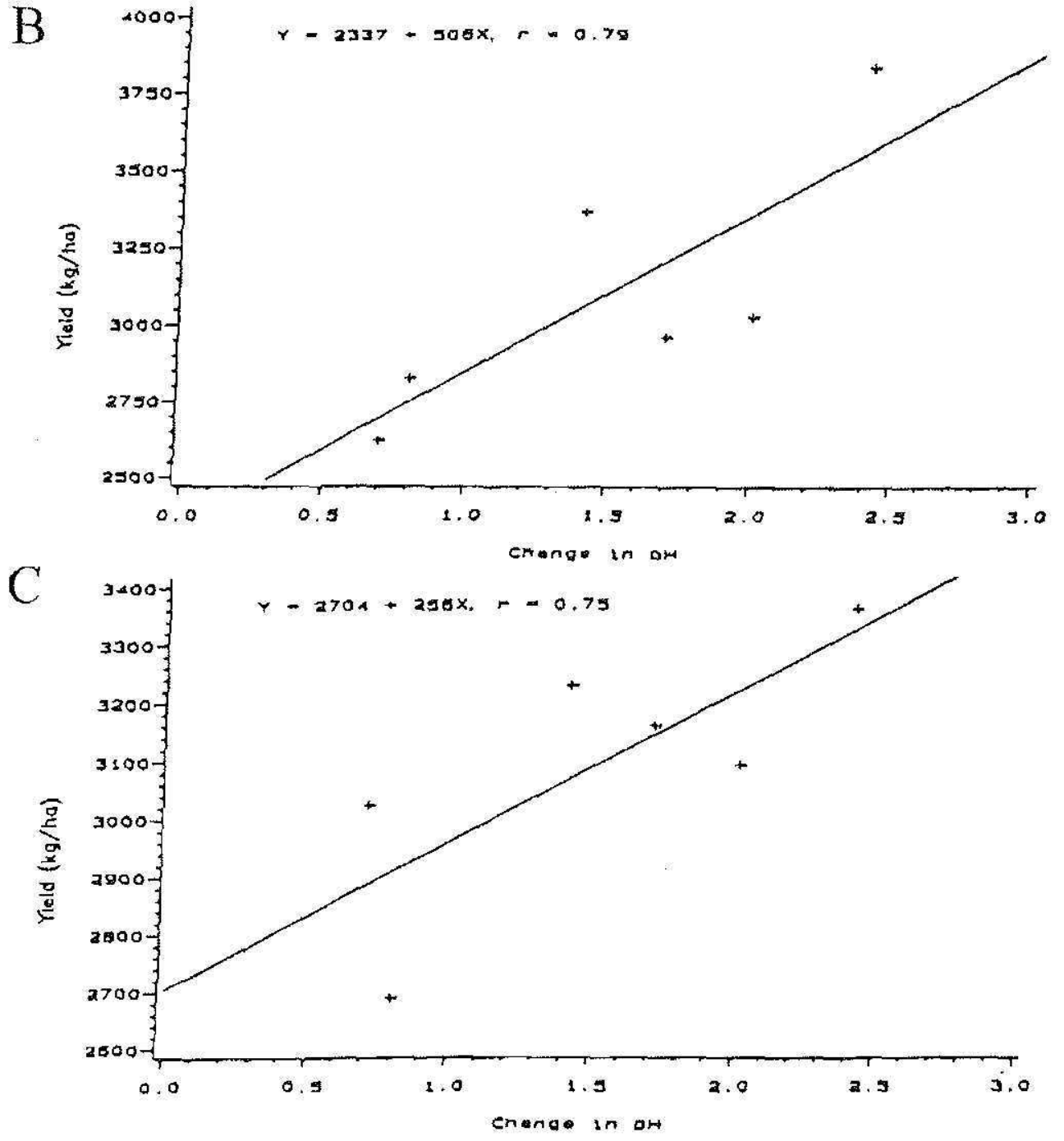

Fusure 2. The association between change in $\mathrm{pH}$ and seed yields on (A) Sharkey clay (Keiser, 1983); (B) Loring sili loam (Marianna, 1983); and (C) Crowley silt loam (Stuttgard, 1983). 

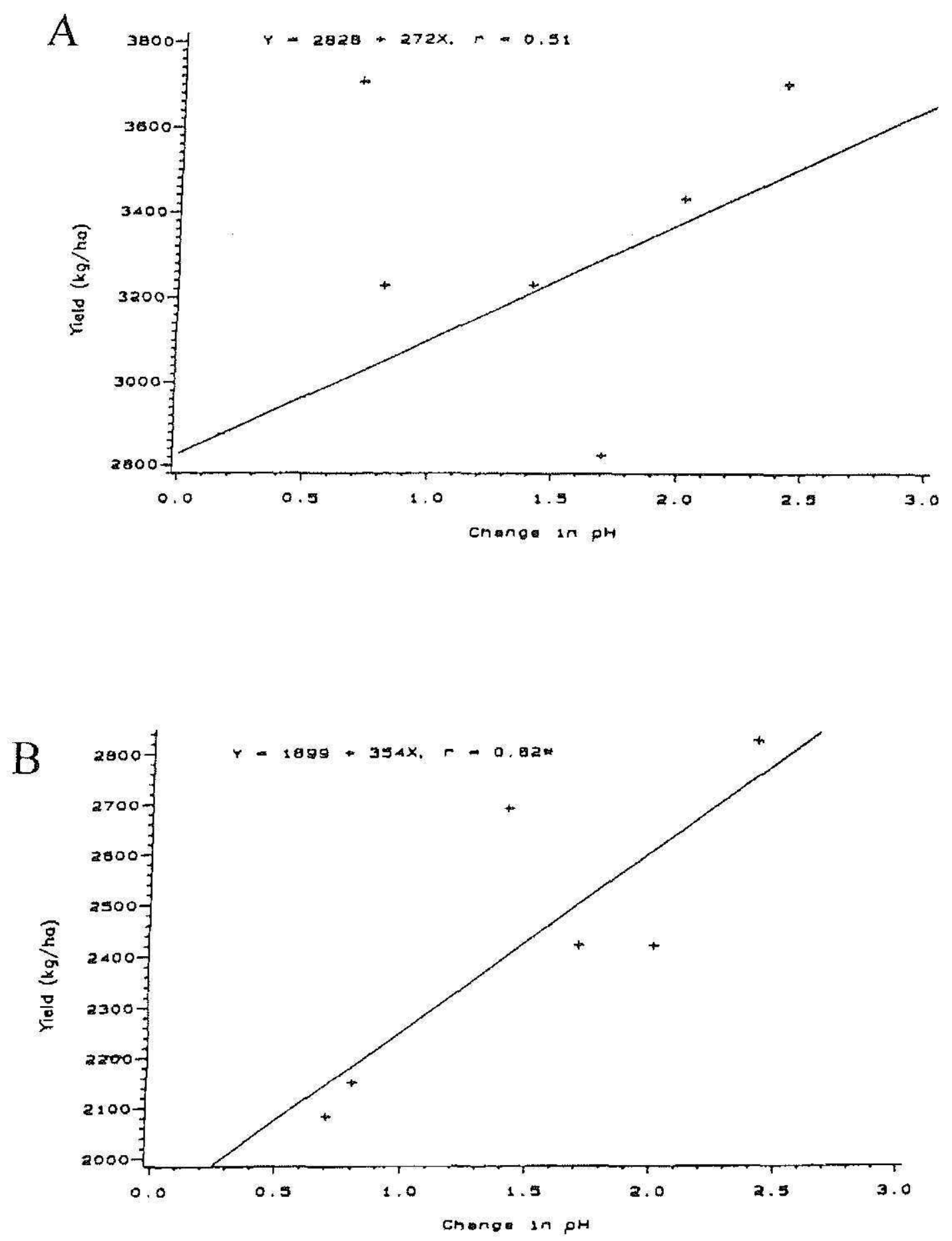

FICURE 3. The association between change in $\mathrm{pH}$ and seed yields on (A) Sharkey clay (Keiser, 1984); and (B) Loring silt loam (Marianna, 1984).

close to the average of the two previous years. At Marianna, the correlation between $\mathrm{H}^{+}$efflux and yield was significant $(\mathrm{r}=0.82)$, and the top four cultivars exhibited a $12 \%$ increase in yield over that of the lower two cultivars (Figure 3B) (Longer and Moore, 1985). 


\section{PUERTO RICO STUDY}

\section{Oxisol (Isabela)}

Soybean mean yields at Isabela ranged from $925 \mathrm{~kg} / \mathrm{ha}$ for Terra Vig 708 to 1,956 kg/ha for Davis (Table 4). Davis, Forrest, and Lee 74, with high to medium $\mathrm{H}^{+}$efflux capacity, had the highest yields although there were no significant differences among them. The Isabela Oxisol was the most nutrient-deficient soil of the three sites (Table 3) (Abruña et al, 1976; Bonnet, 1968). At this site, the cultivars experienced potassium deficiency at all stages of growth, with plants exhibiting short internodes, yellowed leaves and reduced flowering. The potassium deficiency would have restricted net photosynthesis and depressed transpiration and chlorophyll synthesis (Abruña et al, 1976; Henderson and Kamprath, 1970). Sufficiency ranges for potassium in soybean leaf tissue lie between 1.35 and 2.30\% (Sabbe et al., 1972). Among the three sites, the lowest yields were those at Isabela; however, cultivar Davis, with a high $\mathrm{H}^{*}$ efflux capacity, produced the highest seed yield at this site. Terra Vig 708 demonstrated superior efficiency in nutrient accumulation per unit of biomass (Table 4). Experimental evidence indicates that vegetative tissues of the soybean plant serve as a reservoir for mineral nutrients during vegetative growth and that minerals are translocated to the seed during the pod-filling stages (Hammond et al., 1951; Henderson and Kamprath, 1970; Sabbe et al., 1972). This finding was currently indicated by $50 \%$ reduction in the plant's potassium contents between the flowering (R1) and beginning seed formation (R5) stages. Cultivar Davis was also the most efficient in ex-

TABLE 4. ... Yield, harvest index: values, and $\triangle p H$ for soybean cultivars grown on Oxisol (Isabela).

\begin{tabular}{|c|c|c|c|c|}
\hline \multirow[b]{2}{*}{ Cultivar } & \multicolumn{2}{|c|}{ Yield } & \multirow[b]{2}{*}{ Harvest index } & \multirow[b]{2}{*}{$\triangle \mathrm{pH}=$} \\
\hline & Seed & Biomass & & \\
\hline \multicolumn{5}{|c|}{ 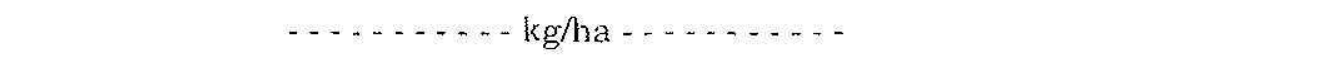 } \\
\hline Pioneer 5482 & $1,151 b^{\prime}$ & $2,890 \mathrm{~b}$ & 39.8 & $2.4 \mathrm{a}$ \\
\hline Davis & $1,956 \mathrm{a}$ & $6,290 \mathrm{a}$ & 31.1 & $2.0 \mathrm{~b}$ \\
\hline Forrest & $1,674 \mathrm{ab}$ & $4,340 \mathrm{ab}$ & 38.6 & $1.4 \mathrm{~d}$ \\
\hline Lee 74 & $1,282 \mathrm{ab}$ & $3,310 \mathrm{~b}$ & 38.7 & $1.7 \mathrm{c}$ \\
\hline Hood 75 & $1,086 b$ & $3.070 \mathrm{~b}$ & 35.4 & $0.8 \mathrm{e}$ \\
\hline Terra Vig 708 & $925 \mathrm{~b}$ & $2,240 \mathrm{~b}$ & 41.3 & $0.7 \mathrm{e}$ \\
\hline
\end{tabular}

'Means in a columb followed by the same letter are not significantly different. $(\mathrm{P}<$ $0.05)$.

${ }^{2} \triangle \mathrm{pH}$ is the depression from $\mathrm{pH} 7$. 
TABLE 5.-Leaf nutrient analysis at flowering for soybeans grown on Oxisol (Isabela).

\begin{tabular}{|c|c|c|c|c|c|c|}
\hline Cultivar & $N$ & $p$ & $\mathrm{~K}$ & $\mathrm{Ca}$ & Mrg & $\mathrm{K} /(\mathrm{Ca}+\mathrm{Mg})$ \\
\hline & \multicolumn{2}{|c|}{ 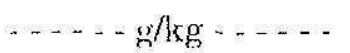 } & \multicolumn{3}{|c|}{$\ldots \ldots$ meq $/ 100 \mathrm{~g} \ldots \ldots$} & \\
\hline Pioneer 5482 & $40.1 b c$ & 2.4.ab & 19.44 & $114.77 c$ & 61.68 & 0.11 \\
\hline Davis & $42.6 a$ & $2.5 \mathrm{ab}$ & 21.48 & $116.27 \mathrm{bc}$ & 63.32 & 0.12 \\
\hline Forrest & $43.8 \mathrm{a}$ & $2.6 \mathrm{a}$ & 20.97 & $106.29 \mathrm{c}$ & 57.56 & 0.13 \\
\hline Lee 74 & $43.3 \mathrm{a}$ & $2.5 a b$ & 20.46 & $105.79 \mathrm{c}$ & 55.10 & 0.13 \\
\hline Hood 75 & $39.3 c$ & $2.3 \mathrm{bc}$ & 18.41 & $130.74 a$ & 66.61 & 0.09 \\
\hline Terra Vig 708 & $38.8 \mathrm{c}$ & $2.0 \mathrm{c}$ & 17.65 & $125.75 \mathrm{ab}$ & 55.92 & 0.10 \\
\hline
\end{tabular}

Means in a column followed by the same letter are not significantly different $(\mathrm{P}<$ $0.05)$.

tracting soil potassium (Tables 5 and 6 ). The $\mathrm{K} /(\mathrm{Ca}+\mathrm{Mg}$ ) ratio was higher for Davis, Forrest, and Lee 74 at the flowering and beginning seed stages than for the other cultivars (Tables 5 and 6). The correlation between seed yield and total biomass was highly positive (Figure 4A).

Leaf potassium content was positively correlated with yield (Figure $4 \mathrm{~B}), \mathrm{H}^{+}$efflux $(\mathrm{r}=0.64)$, and the $\mathrm{K} /(\mathrm{Ca}+\mathrm{Mg})$ ratio $(x=0.65)$. Cultivars having a high $\mathrm{H}^{+}$efflux appeared to be the most efficient in extracting soil potassium and increasing yield. A closer correlation between the $\mathrm{KJ}$ $(\mathrm{Ca}+\mathrm{Mg})$ ratio with seed yield (Figure $4 \mathrm{C})$ than with biomass $(\mathrm{r}=0.57)$ may indicate an inherent plant priority for reproductive tissue formation.

Biomass was positively correlated with the $\mathrm{K} /(\mathrm{Ca}+\mathrm{Mg})$ ratio at the beginning seed stage of development $(x=0.74)$. Maximum dry matter yield and nutrient uptake occur during the early pod-filling stage of

TABLE 6.-Leaf nutrient analysis at beginning seed stage for soybeans grown on Oxisol (Isabela).

\begin{tabular}{|c|c|c|c|c|c|c|}
\hline Cultivar & $\mathrm{N}$ & $\mathrm{P}$ & K & $\mathrm{Ca}$ & $\mathrm{Mg}$ & $\mathrm{K} /(\mathrm{Ca}+\mathrm{Mg})$ \\
\hline & \multicolumn{2}{|c|}{$\ldots \ldots g / k g-\ldots$} & \multicolumn{3}{|c|}{$\ldots . . . . m e q / 100 g$. . . . . . } & \\
\hline Pioneer 5482 & $24.3 b^{1}$ & $1.8 \mathrm{~cd}$ & 8.18 & $161.18 \mathrm{bc}$ & 97.94 & 0.03 \\
\hline Davis & $31.6 \mathrm{a}$ & $2.1 \mathrm{ab}$ & 11.76 & $153.19 \mathrm{~cd}$ & 99.59 & 0.05 \\
\hline Forrest & $31.9 a$ & $2.3 \mathrm{a}$ & 11.00 & $144.21 \mathrm{~d}$ & 89.71. & 0.05 \\
\hline Lee 74 & $29.2 a$ & $2.1 a b$ & 11.76 & $151.70 \mathrm{~cd}$ & 101.23 & 0.05 \\
\hline Hood 75 & $28.5 a$ & $2.0 \mathrm{bc}$ & 9.72 & $170.16 \mathrm{ab}$ & 100.41 & 0.04 \\
\hline Terra Vig 708 & $24.9 \mathrm{~b}$ & $1.8 \mathrm{~d}$ & 8.70 & $180.64 \mathrm{a}$ & 107.00 & 0.03 \\
\hline
\end{tabular}

'Means in a column followed by the same letter are not significantly different $(\mathrm{P}<$ 0.05 ). 


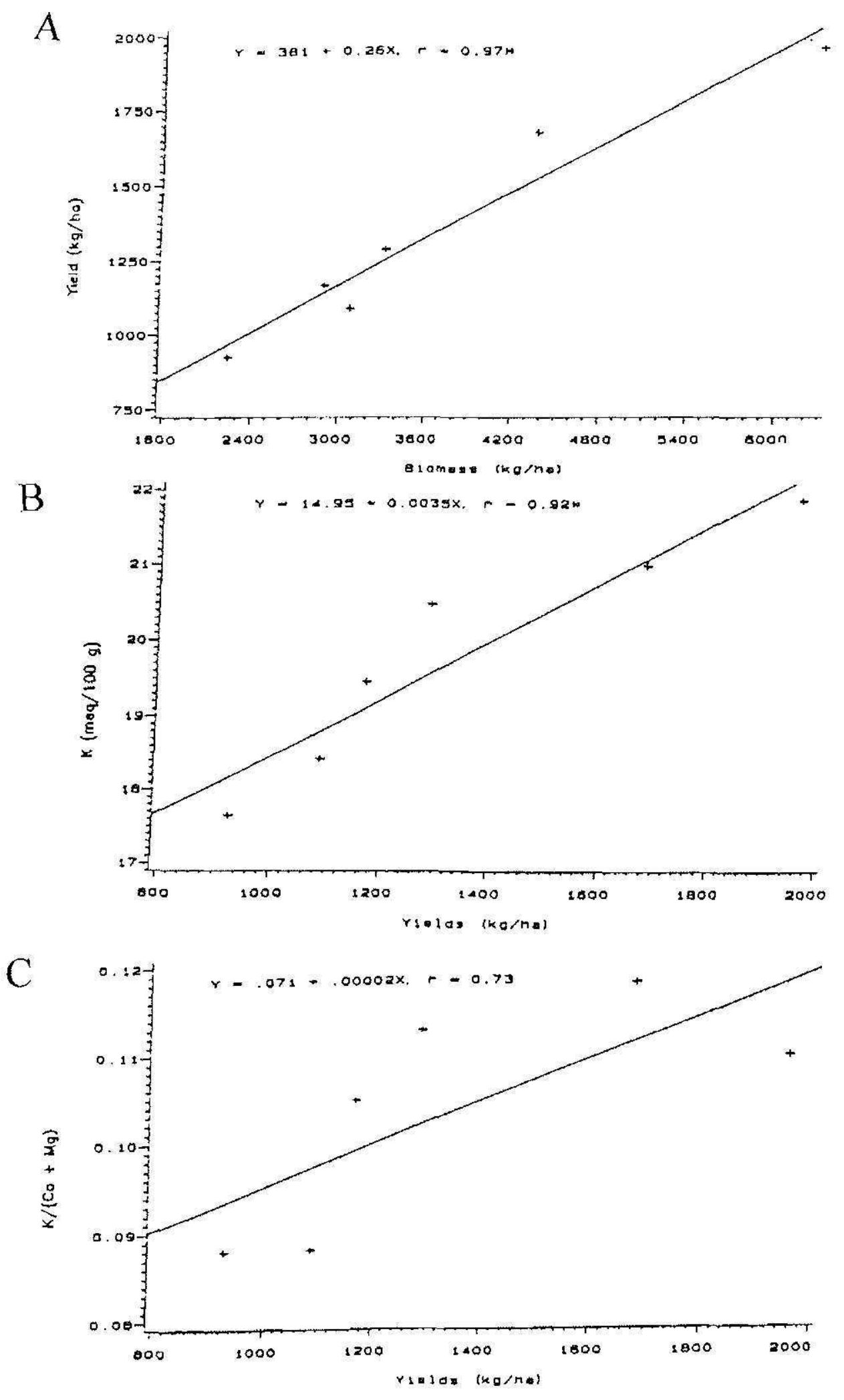

FlGtikl 4. The association between (A) biomass and seed yields; (B) seed yields and the leaf potassium content at the flowering stage; and (C) seed yields and the $\mathrm{K} / \mathrm{Ca}+\mathrm{Mg}$ ) ratio at the flowering stage, on an Oxisol (Isabela). 
growth (Terman, 1977). The harvest index was negatively correlated to leaf potassium content $(r=-0.60)$ and to the $\mathrm{K} /(\mathrm{Ca}+\mathrm{Mg})$ ratio $(r=-$ 0.52 ) at the beginning seed stage of development. This finding could indicate deficiencies in the distribution of dry matter at the organizational level of the whole plant (Spaeth et al., 1984).

\section{Ultisol (Corozal)}

Soybean yields at Corozal ranged from $1,711 \mathrm{~kg} / \mathrm{ha}$ for Terra Vig 708 to $2,616 \mathrm{~kg} / \mathrm{ha}$ for Davis (Table 7). With but one exception, the cultivars with medium to high ( 1.5 to 2.0$) \mathrm{H}^{+}$efflux produced the highest yields. Lee 74 produced $1,160 \mathrm{~kg} / \mathrm{ha}$ more biomass but produced the same seed yield as Forrest (Table 7). Forrest had a yield increase of only $3.6 \%$ compared to that of Hood 75, which had a 100\% increase over that at Isabela (Tables 4 and 7). Except for Davis, there were no significant differences among cultivars in biomass produced at Corozal. The overall yield increase was about $625 \mathrm{~kg} / \mathrm{ha}$ compared to soybeans grown at Isabela (Tables 4 and 7). Manganese availability at Corozal might possibly have enhanced nitrogen utilization at this site (Table 3) (Mengel and Kirbby, 1982). This micronutrient was not detected at Isabela (Table 3).

There was a generally higher potassium accumulation at the flowexing stage than at the beginning seed formation stage (Tables 8 and 9 ). At this stage, potassium accumulation for all soybean cultivars was 3.6 times higher at Corozal than at Isabelia (Tables 5 and 8). Potassium seems to have enhanced the efficiency of nitrogen utilization, as sug-

TABLE 7. - Yield, harvest index values, and $\triangle p H$ for soybean cultivars grown on Ulisol (Corozal).

\begin{tabular}{lcccc} 
& \multicolumn{2}{c}{ Yield } & \\
Cultivar & Seed & Biomass & $\begin{array}{c}\text { Harvest } \\
\text { index }\end{array}$ & $\Delta \mathrm{pH}^{2}$ \\
\cline { 2 - 5 } & & & & \\
Pioneer 5482 & $1,854 \mathrm{~b}$ & $4,870 \mathrm{~b}$ & 38.1 & $2.4 \mathrm{a}$ \\
Davis & $2,616 \mathrm{a}$ & $7,489 \mathrm{a}$ & 34.9 & $2.0 \mathrm{~b}$ \\
Forrest & $1,734 \mathrm{~b}$ & $4,51.0 \mathrm{~b}$ & 38.4 & $1.4 \mathrm{~d}$ \\
Lee 74 & $1.734 \mathrm{~b}$ & $5,670 \mathrm{~b}$ & 30.6 & $1.7 \mathrm{c}$ \\
Hood 75 & $2,183 \mathrm{a}$ & $5,730 \mathrm{~b}$ & 38.1 & $0.8 \mathrm{e}$ \\
Terra Vig 708 & $1,711 \mathrm{~b}$ & $4,980 \mathrm{~b}$ & 34.4 & $0.7 \mathrm{e}$
\end{tabular}

Means in a column followed by the same letter are not significantly different $(\mathrm{P}<$ $0.05)$.

$\mathrm{ApH}$ is the depression from $\mathrm{pH} 7$. 
TABLA 8. - Leaf nutrient analysis at flowering for soybeans groun on Ultisol (Corozal).

\begin{tabular}{|c|c|c|c|c|c|c|}
\hline Cultivar & N & $\mathrm{P}$ & $\mathrm{K}$ & Ca & $\mathrm{Mg}$ & $\mathrm{K} /(\mathrm{C} \mathrm{il}+\mathrm{M} \mathrm{gg})$ \\
\hline & \multicolumn{2}{|c|}{$\ldots . . . \mathrm{g} / \mathrm{kg} \ldots \ldots$} & \multicolumn{3}{|c|}{...... mer $/ 100 \mathrm{~g}$....... } & \\
\hline Pioneer 5482 & 47.8 & $3.0 \mathrm{ab}$ & 75.45 & $80.34 \mathrm{c}$ & 38.68 & 0.6339 \\
\hline Davis & 49.4 & $3.2 \mathrm{a}$ & 78.00 & $85.33 b c$ & 46.09 & 0.5935 \\
\hline Forrest & 47.5 & $2.9 \mathrm{bc}$ & 71.10 & $90.32 \mathrm{ab}$ & 43.62 & 0.5308 \\
\hline Lee 74 & 47.5 & $3.2 \mathrm{a}$ & 72.38 & $81.84 \mathrm{c}$ & 40.33 & 0.5924 \\
\hline Hood 75 & 49.6 & $3.0 \mathrm{ab}$ & 66.24 & $91.82 \mathrm{a}$ & 46.09 & 0.4803 \\
\hline Terra Vig 708 & 47.3 & $2.7 \mathrm{c}$ & 73.66 & $89.82 \mathrm{ab}$ & 42.80 & 0.5554 \\
\hline
\end{tabular}

Means in a column followed by the same letter are not significantly different $(P<$ $0.05)$.

gested by the yields obtained at the Corozal location versus those at Isabela. Forrest, with a high capacity for $\mathrm{H}^{+}$effux, had the most favorable conversion of biomass to seed (Table 7). Soybean nutrient uptake of nitrogen, phosphorus, and potassium generally declines through the later reproductive stages while calcium and magnesium uptake increases (Hammond et al., 1951; Harper, 1971). Leaf analyses for nitrogen, phosphorus, potassium, calcium, and magnesium, for all three stages, reflect this nutrient absorption pattern of soybean plants (Tables 5, 6, 8, 9, 11, and 12).

Yields were positively correlated to biomass (Figure $5 \mathrm{~A}$ ) and to the $\mathrm{K} /(\mathrm{Ca}+\mathrm{Mg}$ ) ratio at flowering (Figure $5 \mathrm{~B}$ ). For those cultivars with highest $\mathrm{H}^{+}$efflux, dispersion along the line of determination was similar. The associations of $\mathrm{H}^{*}$ efflux to leaf potassium content $(x=0.67)$ and to the $\mathrm{K} /(\mathrm{Ca}+\mathrm{Mg})$ ratio (Figure $5 \mathrm{C}$ ) were positive. Pioneer 5482 and Davis retained the leading positions for potassium accumulation. The

TABLE 9.-Leaf nutrient analysis at beginning seed for soybeans groun on Cltisol (Corozal).

\begin{tabular}{|c|c|c|c|c|c|c|}
\hline Cultivar & $\mathrm{N}$ & $\mathrm{P}$ & $\mathrm{K}$ & $\mathrm{Ca}$ & $\mathrm{Mg}$ & $\mathrm{K} /(\mathrm{Ca}+\mathrm{Mg})$ \\
\hline & \multicolumn{2}{|c|}{$\ldots-\ldots g / k g \ldots}$. & \multicolumn{3}{|c|}{$\ldots . . . . m e q / 100 \mathrm{~g} \ldots . .}$. & \\
\hline Pioneex 5482 & $28.9 c^{3}$ & $2.4 \mathrm{~cd}$ & $48.59 \mathrm{a}$ & $127.24 \mathrm{~cd}$ & $29.63 h$ & 0.3097 \\
\hline Davis & $35.9 \mathrm{a}$ & $2.7 b c$ & $43.73 b$ & $126.25 \mathrm{~d}$ & $34.75 a$ & 0.2719 \\
\hline Forrest & $34.0 \mathrm{a}$ & $2.9 \mathrm{ab}$ & $45.01 a b$ & $117.26 \mathrm{e}$ & $28.81 \mathrm{~b}$ & 0.3081 \\
\hline Lee 74 & $29.3 b c$ & $3.2 \mathrm{a}$ & $42.20 \mathrm{~b}$ & $131.74 \mathrm{c}$ & $37.04 \mathrm{a}$ & 0.2500 \\
\hline Hood 75 & $33.1 a b$ & $2.7 \mathrm{bc}$ & $33.50 \mathrm{c}$ & $143.21 \mathrm{~b}$ & $35.39 \mathrm{a}$ & 0.1876 \\
\hline Terra Vig 708 & $28.5 c$ & $2.2 \mathrm{~d}$ & $41.43 b$ & $149.20 \mathrm{a}$ & $37.04 \mathrm{a}$ & 0.2224 \\
\hline
\end{tabular}
$0.05)$.

'Means in a column followed by the same letter are not significantly different $(P \subset$ 
T.MBE 10.-Seed and biomass yields, harvest index, and $\triangle p H$ for soybean cultivars grown on Vertisol (Lajas).

\begin{tabular}{|c|c|c|c|c|}
\hline \multirow[b]{2}{*}{ Cultivar } & \multicolumn{2}{|c|}{ Yield } & \multirow{2}{*}{$\begin{array}{l}\text { Harvest } \\
\text { index }\end{array}$} & \multirow{2}{*}{$\triangle \mathrm{pH}$} \\
\hline & Seed & Biomass & & \\
\hline \multicolumn{5}{|c|}{$\ldots \ldots \ldots$ kgfha $\ldots \ldots \ldots$} \\
\hline Pioneer 5482 & $2,568 \mathrm{bc}$ & $6,330 \mathrm{a}$ & 40.6 & $2.4 \mathrm{a}$ \\
\hline Davis & $3,517 \mathrm{a}$ & $7,500 \mathrm{a}$ & 46.9 & $2.0 \mathrm{~b}$ \\
\hline Forrest & $2,724 \mathrm{ab}$ & $6,530 \mathrm{a}$ & 41.7 & $1.4 \mathrm{~d}$ \\
\hline Lee 74 & $2,339 \mathrm{bc}$ & $5,950 \mathrm{a}$ & 39.3 & $1.7 \mathrm{c}$ \\
\hline Hood 75 & $2,813 a b$ & $6,190 \mathrm{a}$ & 45.4 & $0.8 \mathrm{e}$ \\
\hline Tejta Vig 708 & $2,878 \mathrm{c}$ & $5,156 \mathrm{~b}$ & 36.4 & $0.7 \mathrm{e}$ \\
\hline
\end{tabular}

Means in a column followed by the same letter are not significantly different ( $P$ $0.05)$.

$\triangle \mathrm{pH}$ is the depression from $\mathrm{pH} 7$.

same pattern was observed at the beginning seed formation stage for the same two variables with $\mathrm{H}^{+}$efflux $(\mathrm{r}=0.77)$. Results at this site strongly suggest that the cultivars encountered a richer soil for nutrient uptake and their efficiency in absorption was therefore reflected in their capacity for $\mathrm{H}^{+}$efflux. The slope of the line in the correlation of biomass and yields (Figure $5 \mathrm{~A}$ ) was 25 degrees. This was only five degrees greater than the slope of the line at Isabela (Figure 4A), but seed yield increased by $626 \mathrm{~kg} / \mathrm{ha}$, or $46 \%$.

Vertisol (Lajas)

At Lajas, cultivar Davis produced the higher yield, $87 \%$ greater than the yield by cultivar Terra Vig 708 (Table 10). Cultivar Hood 75

TABLE 11. - Leaf nutrient anulysis at flowering for soybeans grown on Vertisol (Lajas).

\begin{tabular}{|c|c|c|c|c|c|c|}
\hline Cultivar & $N$ & $\mathrm{P}$ & K & $\mathrm{Ca}$ & $\mathrm{Mg}$ & $\mathrm{K} /(\mathrm{Ca}+\mathrm{Mg})$ \\
\hline & \multicolumn{2}{|c|}{$\ldots \ldots g / k g \ldots$} & \multicolumn{3}{|c|}{...... meq/100 g ........ } & \\
\hline Pioneer 5482 & $34.5 a^{1}$ & $4.1 \mathrm{a}$ & $47.31 \mathrm{a}$ & $94.31 \mathrm{bc}$ & 61.73 & 0.3032 \\
\hline Davis & $36.1 \mathrm{a}$ & $4.4 \mathrm{a}$ & $51.91 \mathrm{a}$ & $98.30 \mathrm{ab}$ & 63.37 & 0.3211 \\
\hline Forrest & $36.2 \mathrm{a}$ & $4.2 \mathrm{a}$ & $53.71 \mathrm{a}$ & $81.84 \mathrm{c}$ & 57.61 & 0.3852 \\
\hline Lee 74 & $38.0 \mathrm{a}$ & $4.8 \mathrm{a}$ & $51.15 \mathrm{a}$ & $86.83 \mathrm{bc}$ & 55.14 & 0.3603 \\
\hline Hood 75 & $38.3 \mathrm{a}$ & $4.6 \mathrm{a}$ & $48.85 a$ & $100.80 a$ & 66.67 & 0.2917 \\
\hline Terra Vig 708 & $37.1 a$ & $4.3 a$ & $50.13 a$ & $96.13 a b$ & 55.97 & 0.3292 \\
\hline
\end{tabular}

'Means in a column followed by the same letter are not significantly different $(\mathrm{P}<$ $0.05)$. 
TABLA: 12. - Leaf mutrient analysis at beginning serel for soybeans grown on Vertisol (Lajas).

\begin{tabular}{|c|c|c|c|c|c|c|}
\hline Cultivar & N & $\mathrm{P}$ & $\mathrm{K}$ & $\mathrm{Ca}$ & $\mathrm{M} g$ & $\mathrm{~K} /(\mathrm{Ca}+\mathrm{Mg})$ \\
\hline & \multicolumn{2}{|c|}{$\ldots . . .6 / k g-\ldots$} & \multicolumn{4}{|c|}{..... meg/100 g ...... } \\
\hline Pioneer 5482 & $35.6 \mathrm{a}^{2}$ & $4.3 \mathrm{c}$ & $35.80 \mathrm{a}$ & $107.78 a$ & $57.61 a$ & 0.2164 \\
\hline Davis & $36.6 a$ & $3.9 \mathrm{~d}$ & $29.67 \mathrm{a}$ & $144.77 a$ & $51.85 a$ & 0.1509 \\
\hline Forrest & $36.5 a$ & $4.5 b c$ & $36.32 \mathrm{a}$ & $101.80 a b$ & $52.67 a$ & 0.2351 \\
\hline Lee 74 & $36.9 a$ & $4.4 \mathrm{bc}$ & $34.53 \mathrm{a}$ & $105.79 b$ & $58.44 \mathrm{a}$ & 0.2102 \\
\hline Hood 75 & $37.4 \mathrm{a}$ & $5.2 \mathrm{a}$ & $31.71 \mathrm{a}$ & $123.25 \mathrm{a}$ & $65.84 \mathrm{a}$ & 0.1677 \\
\hline Terra Vig 708 & $35.4 \mathrm{a}$ & $4.6 b$ & $34.53 \mathrm{a}$ & $1.17 .76 \mathrm{a}$ & $51.85 \mathrm{a}$ & 0.2036 \\
\hline
\end{tabular}

'Means in a column followed by the same letter are not significantly different ( $\mathrm{P}<$ $0.05)$.

ranked second in seed yield although it had a low $\mathrm{H}^{+}$efflux capacity. There were no significant differences in biomass yield among the top five cultivars, with the exception of Terra Vig 708 (Table 10), which followed the same patterm as in the other experiments with the lowest yields (Tables 4, 7, and 10 ).

Davis indicated the highest rate of conversion from biomass to seed (Table 10). The soil contained a higher exchangeable $\mathrm{Na}^{*}$ content, which might have competed with essential nutrients for uptake (Kilmer et al., 1968; Mengel and Kirbby, 1982). Excessive rain at the latter part of the growing season affected yield by causing preharvest sprouting (Dougherty and Boerma, 1984; Yaklich and Cregan, 1981). At all three sites, nutrient accumulation was greater at flowering than at the beginning seed stage (Tables 5, 6, 8, 9, 11, and 12). This difference was less pronounced at the Lajas site (Tables 11 and 12). The association between biomass and yield was high (Figure 6A), as was the association between yield and harvest index (Figure 6B). Leaf potassium content and the $\mathrm{K} /(\mathrm{Ca}+\mathrm{Mg})$ ratio were both negatively correlated to yield at the beginning seed stage, $r=-0.67$, and $r=-0.61$, respectively.

The negative correlation at the beginning seed stage between potassium accumulation and yield indicates a potassium depletion of the rhizosphere soil zone by cultivars with high $\mathrm{H}^{+}$efflux as compared to those of low $\mathrm{H}^{+}$efflux. The Davis and Pioneer 5482 cultivars would accumulate nutrients at a greater rate, because of a higher net $\mathrm{H}^{+}$efflux than Terra Vig 708. Nutrient mobility on this heavy clay soil might be slower than root absorption, thereby resulting in nutrient depletion around the rhizosphere root zone. 


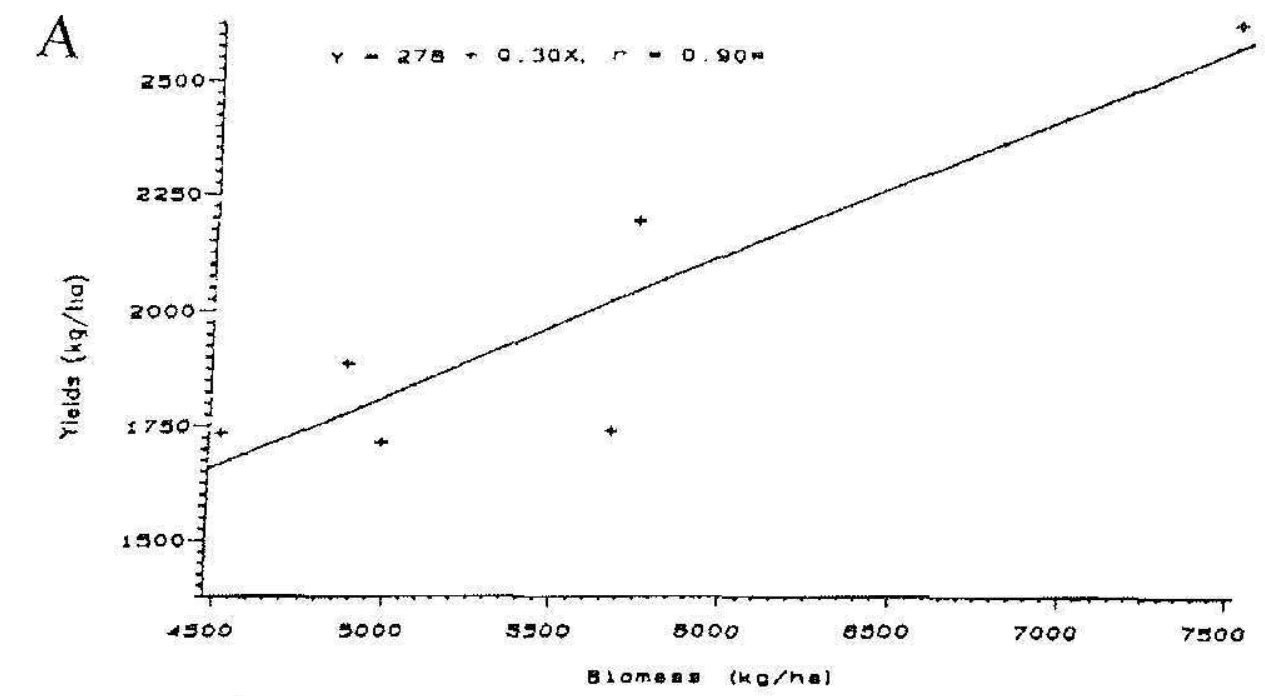

B
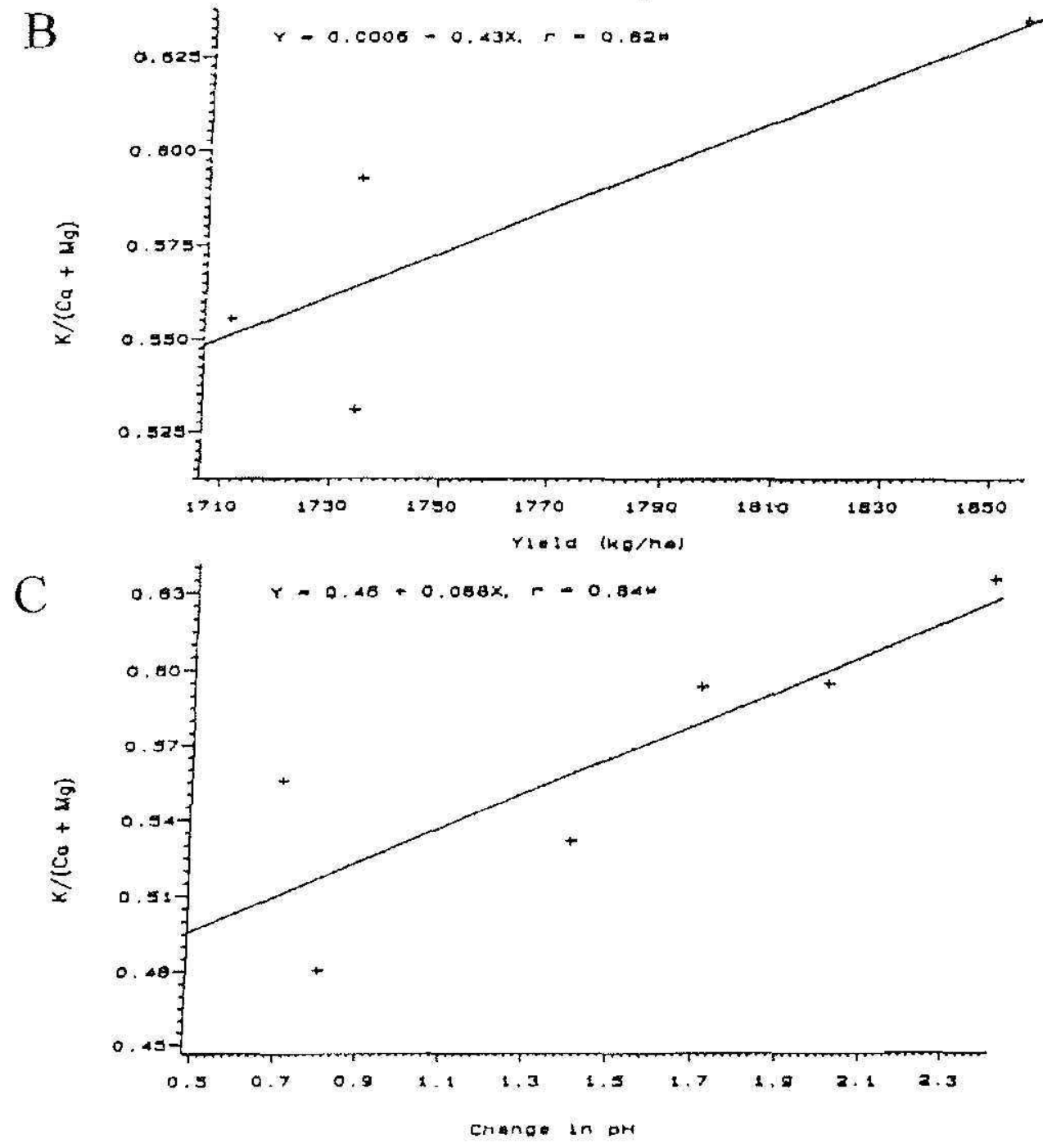

FICrure 5. The association between (A) biomilsis and seed yields; $(B)$ seed yields and the $\mathrm{K} /(\mathrm{Ca}+\mathrm{Mg})$ ratio at the flowering stage; and $(\mathrm{C})$ change in $\mathrm{pH}$ and the $\mathrm{K} /(\mathrm{C} \mathrm{a}+\mathrm{Mg})$ ratio at the flowering stage, on an Ultisol (Corozal). 
J. Agric. Univ. P.R. vOL. 81, NO. 3-4, JULY-OCTOBER 1997177
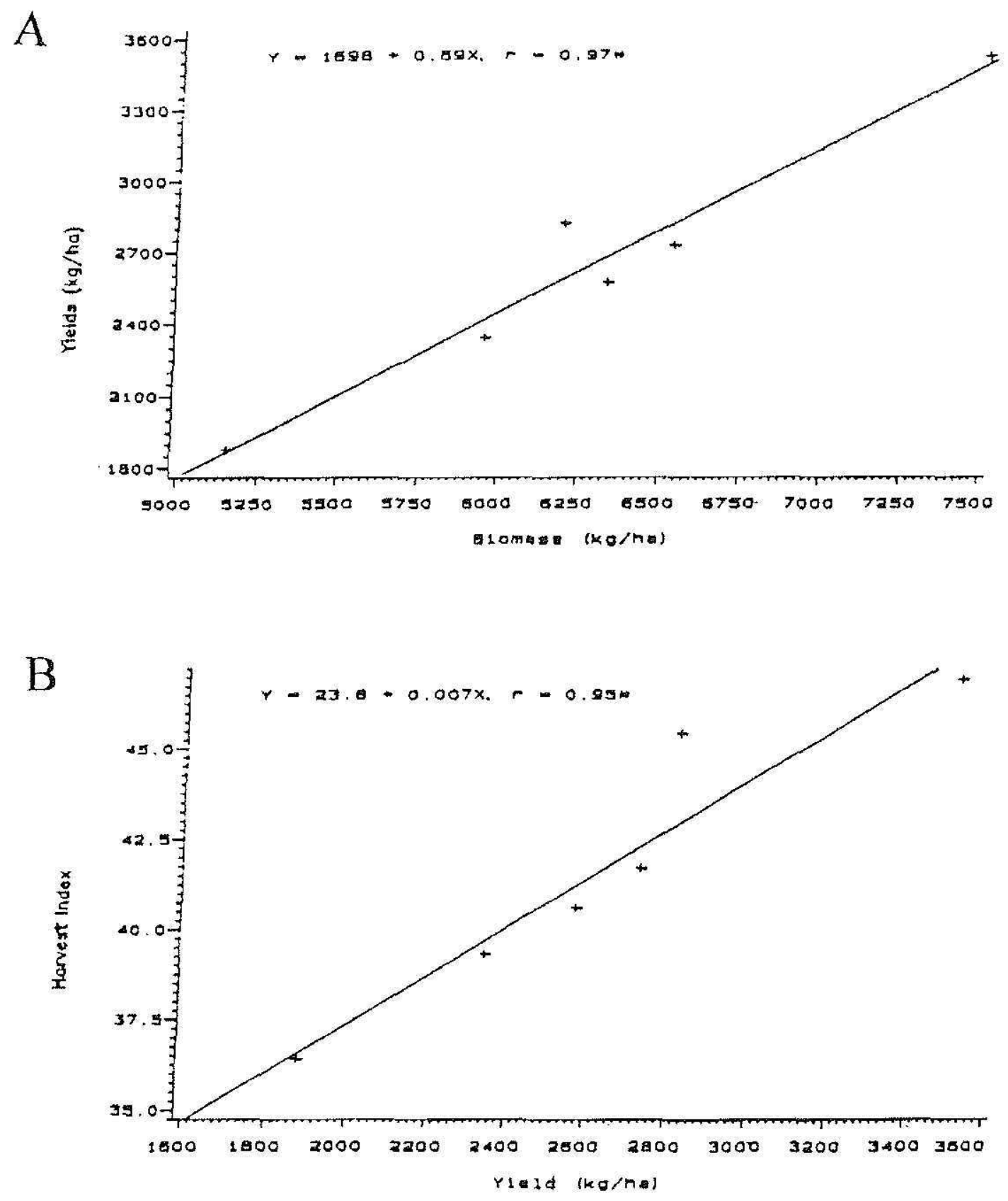

Figure 6 . The association between ( $A$ ) biomass and seed yields; and ( $B$ ) seed yields and harvest index, on a Vertisol (Lajas).

\section{SUMMARY AND CONCLUSIONS}

Hydrogen ion efflux is an important metabolic mechanism in the nutrient uptake by plants. Although recognized as such by many research workers, it has not been widely used as a tool to differentiate nutrient efficient cultivars. The soil solution, acting as a source of nutrients, is the place where the plant utilizes this potential. Cultivars 
will respond better in one soil environment than in another, according to the soil's capacity to meet the plant's demands for nutrients.

At Isabela, on the highly leached, low CEC Oxisol, cultivars with high $\mathrm{H}^{*}$ efflux capacity produced the highest yields and accumulated the largest amounts of nutrients at flowering. The ratio of $\mathrm{K} /(\mathrm{Ca}+\mathrm{Mg})$ was positively correlated to biomass and yields, thus suggesting a pattern of nutrient accumulation up to flowering, and then one of storage as the sinks increased with time. At Corozal, on a medium CEC Ultisol with low $\mathrm{pH}$, there was a yield increase of $46 \%$ over that at Isabela. Those cultivars having high $\mathrm{H}^{+}$effux had the highest potassium uptake and yields. At Lajas, on a high CEC Vertisol containing some sodium, the highest yield was $34 \%$ higher than that at Corozal. The heavy clay soil at the Lajas location may have altered the nutrient uptake pattern from that displayed at other sites. However, the negative correlation at the beginning; seed stage between potassium accumulation and seed yield indicates a greater nutrient depletion from the rhizosphere soil zone by the cultivars having high $\mathrm{H}^{+}$efflux.

The field studies indicate that hydrogen ion efflux from plant roots is an important mechanism for the efficiency of nutrient uptake. A cultivar exhibiting high $\mathrm{H}^{+}$efflux will respond with its fullest yield potential on those soils that can meet its nutrient demand. Those soils having a high nutrient-rechargeable capacity are best able to satisfy these nutrient demands.

\section{LITERATURE CITED}

Abruña, F., J. Vicente-Chandler, J. Figarelja and S. Silva, 1976. Potassium supplying power of the major Ultisols and Oxisols of Puerto Rico. I. Agric. Univ. P.R. 60(1):4560 .

Bomet, J. A., 1968. La Ciencia del Suelo. Colegio de Ingenieros, Arquitectos y Agrimensores de P. R., San Juan, ?.R.

Bonnet-Benitez, J. A., 1983. Evaluación de la Nueva Clasificacion Taxonómica de los Suelos de Puerto Rico. Univ. of P.R. Agr. Exp. Sta. Publ. 147.

Caldwell, B. E. (ed.), 1973. Soybeans: Improvement, production and uses, Amex: Soc. Agron., Madison, Wisconsin.

Cheeseman, J. M. and C. Enkoji, 1984. Proton efflux from roots of intact Spergularia marina plants. J. Exp. Bol. 35:1048-1052.

Dougherty, R.W. and H. E. Boerma, 1984. Genotype variation in resistance to prebarvest sprouting in soybean. Crop Sci. 24:683-686.

Fehr, W. R. and C. E. Caviness, 1977. Stage of soybean development. Spec Rep. 80, Iowa State Univ, Ames, lowa.

Cardner, F. P., R. B. Brent and R. L. Mitchell, 1985. Physiology of crop plants. Iowa State Univ. Press, Ames, Iowa.

Glass, A. D. M. and M. Y. Siddiqi, 1982. Cation-stimulated $H^{\cdot}$ efflux by intact roots of barley. Plant Cell Environ. 5:385-393.

Hammond, H. L., C. A. Black and A. G. Norman, 1951. Nutrient uptake by soybeans on two Iowa soils. Iowa Agric. Exp. Sta. Res. Bull. 384. 
Harpor, J. E., 1971. Seasonal nutrient uptake and accumulation patterns in soybeans. Crop Sci. 11:347-3.50.

Haschke, H. P. and C. Lüttge, 1973. Beta-Indolylessigsaure (-IFS)-abhangiger K"-H* Austauschmechanismu: und Strekungswachstum bei Avena - Koleoptilen. Z. Naturforsch. $28 \mathrm{C}: 555-558$.

Henderson, J. B. and E. J. Kamprath, 1970. Nutrient and dry matter accumulation in soybean. North Carolina Exp. Sta. Tech. Bull. 197.

Kilmer, V. J., S. E. Younts and N. C. Brady (eds.), 1968. The role of potassium in agriculture. Amer: Soc. Agron., Madison, Wisconsin.

Leggett, J. E. and M. H. Frere, 1971. Growth and nutrient uptake by soybean plants in nutrient solutions of graded concentrations. Plant Physiol. 48:457-460.

Leggelt, J. E. and W. A. Gilbert, 1969. Magnesium uplake by soybeans. Plant Physiol. 44:1182-1186.

Lin, W., 1979. Potassium and phosphate uptake in corn roots. Plant Physiol. 63:952-955.

Little, T. M. and F. J. Hills, 1978. Agricultural Experimentation. John Wiley and Sons, New York.

Longer, D. E., C. E. Caviness and S. Moore, 1984. Soybean varietal performance, 1983. Ark. Farm Res. 33(2):10-11.

Longer, D. E., C. E. Caviness, H. J. Walters and R. D. Briggs, 1983. Soybean varietal performance, 1982. Ark. Farm Res. 32(1):10-11.

Longer, D. E, and S. Moore, 1985. Soybean varietal performance, 1984. Ark. Farm Res. 34(2):10-11.

Lugo-López, M. A., L. J. Bartelli and F. Abruna, 1973. An overview of the soils of Puerto Rico: Classification and physical, chemical and mineralogical propertics. Univ. P.R. Agr: Exp. Sta. Publ. 79.

Lugo-López, M. A. and L. H. Rivera, 1976. Taxonomic classification of the soils of Puerto Rico, 1975. Univ. P.R. Agr. Exp. Sta. Bull. 245.

Lundegarth, H., 1942. Electrochemical relations between the root system and the soil. Soil Sri. 54:177-189.

Lüttge, U. and N. Higinbotham, 1979. Transport in plants. Springer-Verlag, New York.

Maré, E., P. Lado, F. Rasi-Caldogno, R. Columbo and M. I. De Michelis, 1974. Evidence for the coupling of proton extrusion to $K$ uptake in pea internode segments treated in fusicoccin or auxin. Plant Sci. Lett. 3:365-379.

Mengel, K. and E. A. Kirbby, 1982. Principles of plant nutrition. International Potash Institute, Bern, Switzerland.

Norman, A. G. (ed.), 1978. Soybean physiology, agronomy and utilization. Academic Pross, New York.

Osterhaut, W. J. N., 1936. The absorption of electrolytes in large plant, cells. Bot. Rev. $2: 283-31.5$.

Patterson, S., 1978. Varietal differences in rubidium uptake efficiency of barley ronts. Physiol Plant. 44:1-6.

Pitman, M. G., 1970. Active H efflux from cells of low salt barley roots during sall accumulation. Plant Physiol, 45:787-790.

Pitman, M. G., N. Schaefer and R. A. Wildes, 1975. Relationship between permeability to potassium and sodium ions and fusicoccin stimulated hydrogen-ion efflux in barley roots. Planta. 126:61-73.

Römheld, V., C. Müller and H. Marschner, 1984. Localization and capacity of proton pump in roots of intact sunflower plants. Plant Physiol. 76:603-606.

Sabbe, W. E., f. L. Keogh, R. Maples and R. Hileman, 1972. Nutrient analysis of Arkansas cotton and soybean leaf tissue. Ark. Foum Res. 21(1):2. 
Soil Survey Sitaff, 1978. Soil Survey of Arkansis. USDA Soil Conservation Service, Wasbington, D.C.

Spaeth, S. C., H. C. Randall, T. R. Sinclaiy and J. S. Vendeland, 1984. Stability of soybean harvest index. Agron. J. 76:482-486.

Stutte, C. A., A. R. Blem and R. T. Weiland, 1979. Single plant seed source for uniform soybean physiology texts. Crop Sci. 19:324-326.

Tekrony, D. M., D. B. Egli and G. Henson, 1981. A visual indicator of physiological maturity in soybean plants. Agron. J. 73:553-556.

Terman, G. L., 1977. Yields and nutrient accumulation by determinate soybeans as affected by appljed nutrients. Agron. . 69:234-238.

Vose, P. B., 1963. Varietal differences in plant nutrition. Herbage Abstr: 3:1-13.

Yaklich, R. W. and P. B. Cregan, 1981. Moisture migration into soybean pods. Crop Sci. 21:791-793. 